\title{
A 'truth universally acknowledged'?: Morphology as an indicator of medieval planned market towns
}

\author{
Abstract \\ The paper explores, through the case study of March, a large town in the northern part of the \\ Cambridgeshire peat fens, the general invariability of interpretation as planned markets of new \\ medieval settlements that include both regular plots and one or more geometric open spaces. It asks \\ whether manorial lords might achieve similar ends to those derived from medieval market grants - \\ an increase in income from rents and tolls - by applying lessons learned from commercial planned \\ settlements in other economic contexts.
}

\section{Keywords}

Medieval market, medieval port, planned settlement, river transport, water management, hythe, common rights, fens.

It is a truth universally acknowledged, that a planned town or village in possession of a geometric open space can fairly reliably be interpreted as a foundation around a medieval market - whether constructed $a b$ initio on a green-field site or added to an existing settlement. ${ }^{1}$ That consensus is solidly based on the publication in 1967 of Maurice Beresford's New Towns of the Middle Ages. The historical geography of medieval towns is so well known today that it is difficult to remember how new Beresford's ideas were at the time; yet his study was so carefully researched, and so wellfounded in documentary and other evidence, that it was widely accepted from the outset and remains a classic. The locational and morphological characteristics of urban settlements he identified are now recognised as diagnostic criteria from which medieval commercial foundations can reliably be inferred, whether on new or existing sites: a location on or near a parish and/or county boundary, the diversion of roads towards the new foundation, the introduction or consolidation of infrastructure through the construction of bridges and causeways, regularity in street plan and property boundaries, surviving or market places, halls and crosses, and, on occasion, commanding relationships between manorial centre and the market place (see also Beresford \& St Joseph 1979). An excitement of publication followed New Towns, as archaeological excavation and morphological analysis explored and confirmed Beresford's conclusions (e.g. Barley 1975; Schofield \& Palliser 1981; Haslam 1984; Hodges \& Hobley 1988).

The substantial scope of Beresford's study was significantly extended in an innovative publication by Christopher Taylor (1982), who pointed out that the same typological characteristics could be found in any number of minor rural settlements. He demonstrated the large extent to which such analyses could be supported by documentary evidence for the grant of a market and/or fair to manorial lords, enthusiastic speculators in search of vast rewards from successful foundations, whether new or simply formalising existing patterns of local trade. In some cases that initial investment was successful, but more frequently the market failed - sometimes quite quickly, in other cases fading away over a couple of centuries, either way leaving in the landscape only the tell-tale geometric boundaries of a once-hopeful market green. The clarity and force of Beresford and Taylor's arguments, subsequently confirmed in extensive archaeological excavation and documentary research, underlies that 'universally acknowledged truth': that a planned town or village in possession of a geometric open space can fairly reliably be interpreted as a foundation around a medieval market.

This paper explores that proposition through the case study of Mercheforde, the large medieval 
predecessor of the modern town of March (Merche) which lies along the banks of the Nene in the northern Cambridgeshire peat fens (Map 1). By 1251, its first documentary record, it was already large settlement of 90 messuages, even though it was at the time just a berewick of the Bishop of Ely's nearby manorial centre at Doddington. Mercheforde is generally believed to have been founded in the early thirteenth century, shortly before it was first documented, well within the peak period for medieval market grants between about 1190 and 1230 (Taylor 1982, 20). The earliest maps of the settlement date from around 1600, and show a plan virtually identical to that of the modern town, the regularity of whose properties appears to indicate a planned origin (discussed in more detail below). The period of its origin, its unusual size compared with other medieval rural settlements of similarly low status, evidence of planning, and its strategic location on the Nene have meant that Mercheforde is usually interpreted as an example of 'a port or hithe at the river crossing' which either developed from a medieval plantation of the thirteenth-century Bishops or was informally encouraged by them (Hall 1987, p. 46; see also Taylor 1973, p. 255). ${ }^{2}$ Such an explanation makes intuitive sense given the geography of fenland and the commercial interests of its ecclesiastical lords.

In the undrained peat fens travel on foot, horse or wagon across a largely waterlogged landscape was particularly difficult. Boats offered the most efficient means of moving people and goods around medieval England, and the waterways of the Cambridgeshire peat fens were 'thronged with traffic' throughout the middle ages (Darby 1974, p. 100; see also Langdon 1993, p. 7; Langdon 2007). Any settlement with access to a natural or man-made watercourse - and especially one (like Mercheforde) on one of the great English rivers - had immediate opportunities to engage with local, regional, national and even international trade. It is little surprise, then, that the remains of, and/or documentary evidence for, public and private medieval hythes can be found in almost every fenland settlement, including the modern town of March (e.g. Taylor 1995, p. 267).

If Mercheforde were a commercial plantation of the thirteenth-century Bishops of Ely, there were plenty of successful international markets and fairs founded on the major fenland rivers to inspire a Bishop's dreams of substantial profits. King's Lynn and St Ives had been new ecclesiastical plantations, while the grant of a twelfth-century grant for a market and fair to the Abbey of Ely transformed the existing town (Oosthuizen 2012, pp. 210-211). The trading enterprises of fenland abbeys and bishops were, furthermore, complex, large-scale and far-flung involving them directly in national and international trade. Substantial agricultural surpluses, aggregated at collection points, were exported both within Britain and into Europe by the abbeys of Ramsey, Thorney, Peterborough and Crowland, and by the abbey and bishopric of Ely, through fenland fairs and ports (Raftis 1957; Page 1934; Biddick 1989; Miller 1951). While many European imports were humdrum - like timber and mill-stones - others were exotic: 'Figs and raisins, almonds, pepper and ginger, nuts and sugar, honey and wine, salmon and porpoises' all found their way by boat into the larders and onto the tables of medieval Bishops of Ely (Miller 1951, p. 85). The Bishop's markets on the Ouse at Ely and on the Nene at Wisbech might, it could be argued, be complemented by another at Mercheforde: the settlement lay half way between Peterbrough and Wisbech, and also provided the first landfall in the Bishop's estate for traffic travelling east along the Nene. A planned market town at Mercheforde, from this perspective, might not only tap passing trade along the river, but also act as a focus for trade to and from a wide hinterland in just the same way that the Abbey of Ramsey's new town at St Ives exploited the similar potential of the Ouse to draw in trade from across Huntingdonshire and west Cambridgeshire (Miller 1951, p. 85, n.4).

Yet arguments for a commercial origin for Mercheford are so problematic that they raise the question of whether everything that looks like a medieval planned town really was one, or whether there might be other explanations for large-scale planned settlements in the middle ages. That question forms the focus for this paper. 


\section{Mercheforde: a commercial origin?}

Although Mercheforde occupies both banks of one of the major rivers of eastern England, and might reasonably be expected to have grown large and wealthy on the basis of trade with passing shipping, any medieval market there remains stubbornly invisible. The first recorded market grant dates from 1670 , and there is no surviving documentary evidence that it was preceded by a medieval trading centre (CA P116/28/20; Pugh 1953; Letters 2003). Nor is there any medieval record of significant trade through the town. The omission is the more stark when other places in Cambridgeshire did achieve national commercial status even though they were less accessible. Burwell, for example, lay 62nd in the list of nationally-important inland ports between 1294 and 1348 even though its hythe lay at the landward end of a fairly long lode linking it to the Cam, while the principal focus of the settlement was nearly another $2 \mathrm{~km}$ further south (Langdon 1993, p. 5; see also Oosthuizen 2012). For all its easy access to the Nene, Mercheforde does not appear anywhere in those lists.

On the other hand, it would fly in the face of reason to suggest that there was no medieval waterborne traffic or trade of any kind to or from Mercheforde. Its location on the Nene, the place of fen products in the manorial economy, and strong evidence for the dominance of boats as the preferred form of medieval transport must have encouraged some trading traffic to and from the settlement (e.g. Langdon 1993, Jones 2000). Customary tenants on the Bishop's Doddington manor were expected to carry goods 'by fresh water' across the breadth of the peat fens - not only to the major centres like Peterborough, Cambridge, Ely, and St Ives, but also to those of the Bishop's manors where land-based transport was difficult, like Fen Ditton, Willingham or Little Downham (CUL EDR G3.27). How feasible is it, then, that it may after all have originated as a planned medieval port and market?

\section{Topography}

Topographical and morphological analysis can often lead to the identification of medieval commercial plantations even where documentary evidence is lacking (cf. Beresford \& St Joseph 1979; Beresford 1988; Taylor 1982). Such new markets tended to be founded where there were easy intersections between waterways carrying regional, national and international traffic, and networks of roads linking them with a wide hinterland. It was not unusual for ecclesiastical and secular manorial lords to undertake engineering works to improve these connections, for example, in canalised river courses that brought a riverbank close to a new market, and in the construction of causeways and bridges to carry travellers across boggy (or even inundated) ground. A regular, planned open space frequently survives in modern settlements, often still carrying a 'market' placeor streetname; there may even be the remains of a medieval market cross or hall; existing roads were re-aligned on new markets; and sometimes planned blocks of freehold properties (burgage plots) were laid out around its sides as an enticement to traders and craftsmen (Beresford 1988; Beresford \& St Joseph 1979; Taylor 1982). If some or all of these locational and morphological characteristics could be identified at Mercheforde, they might breathe fresh life into an apparently moribund case for medieval commercial origins.

One of the strongest arguments for a planned medieval market at Mercheforde is the widespread acceptance that the modern eastward route of the Nene through the town runs along a man-made canal, twelve $\mathrm{km}$ in length, whose banks still rise unnaturally high above the water in the river below (Hall 1987, pp. 46 and 1992, p. 186). The proposition that the necessary engineering work for this diversion was undertaken in support of a new market is based on good contemporary analogies: a fresh twelfth-century course for the river Ouse moved shipping right up against the hythes and market of Ely in the same period in which the Abbey received its market grant; the Welland was diverted by several miles to flow between wide hythes through Crowland close to the site of the Abbey, and a natural watercourse was straightened, widened and deepened to bring river traffic into a broad canal alongside the new market outside the gates of Ramsey Abbey, also in the twelfth 
century (Hall 1996, p. 40; Oosthuizen 2012; Spoerry et al. 2008).

There are, however, two problems in interpreting the origins of the artificial course of the Nene through Mercheforde in this way. The first is in the relatively early date at which the work was apparently carried out, and the second is that there were other, more pressing, reasons for getting it done. The construction of the artificial course for the Nene was almost certainly undertaken in the early eleventh century, that is, more or less at the time that the Abbey of Ely built up a large estate at Doddington (Hall 1987, p. 46; Hart 1966, pp. 220-1). ${ }^{3}$ The re-routing of the Nene appears to have been undertaken long before the heyday of medieval market grants, predating the activities of most entrepreneurial lords by a century or more. Either the Ely monks were prescient, investing in a market which might only become profitable after decades or even centuries, or they had other aims in mind.

Two more convincing (and complementary) clues to the motives behind the re-direction of the Nene lie, first, in the name for its older course and second, in the surface geology of the locality. The later Saxon name for the river appears to have been 'Plantewater', describing a watercourse by that period 'choked and decayed, probably by phragmites, cladium or similar [suckering and spreading] plants' (OE plante, Reaney 1943, p. lix (my addition), 14; Map 2). ${ }^{4}$ The consequence of such obstruction in northern fenland to water flowing from the uplands of Northamptonshire and Huntingdonshire would have been the backing up, even in normal conditions, of large volumes of water across the thousands of acres of the western fen basin between March in the east and Peterborough in the west, Wisbech in the north and Ramsey in the south. The consequences of flooding would be disastrous. Evidence for precisely these conditions can be found in the steady extension of peat to an eventual depth of around $3 \mathrm{~m}$ across the western fenland from the postRoman period onwards, when water levels in the fens rose by around 1.5m (Hall 1992, pp. 6-8; BGS Sheets $158,159,172,173)$. Gradual silting of the river, a recurrent problem resulting from the slow passage of water across the flat fenland floor, exacerbated these problems. ${ }^{5}$ The geological record, millennium after millennium, shows the meandering bed of one major watercourse succeeded by another, often on quite different alignments, as old rivers gradually became blocked by silt and the volume of water accumulating in the basin behind them eventually forced a new course towards the sea (Hall 1987, pp. 11, 38 and 46; BGS Sheets 158, 159, 172, 173).

Water backing up across the fen basin posed a substantial and immediate threat to monastic incomes and peasant livelihoods. The Nene carried water from the uplands of Northamptonshire and Huntingdonshire through the rich meadows and pastures of the fen basin on which great herds of cattle belonging to monastic lords and their tenants fed 'horn under horn'. The health and accessibility of those pastures depended on the avoidance of unseasonable and excessive flooding by efficient water management: as Darby commented, 'the winter floods, provided that they did not last too long, served only to make the meadow richer for the following summer' (1974, p. 62, my emphasis). Any sustained obstruction to the drainage of the Nene would be potentially devastating to grazing in the flat landscape of the peat fens; if water were held up near March, not far from the river's outlet in the Wash, the consequences would be felt across the whole of western fenland.

These conditions posed three problems for the eleventh-century monastic houses among whom the fenland basin was divided. The first was that it was impossible to predict whether a new river-course might be forced naturally within a year or two or perhaps only after decades or even centuries of severe flooding. It was similarly impossible to predict the alignment of any new river. It might lie along a course which beneficially both watered and drained the pastures and meadows of each abbey, but it might as easily benefit the lands of one house at the expense of another. A third problem was that in the late Saxon period a new outlet for the Nene towards the north had been made virtually impossible by the steady growth over previous millennia of raised peat sphagnum bogs. The Plantewater was hemmed in by raised peat to the west and the higher ground of the Doddington estate on the east; once its course had begun to silt and become overgrown, there was no leeway for its waters to find an alternative route towards the north (Hall 1987, pp. 11, 38 and 46). 
Rather than waiting for nature to take its course, it appears that a proactive solution was implemented by diverting the Nene eastwards before the Norman Conquest along a new, shorter, artificial cut that took the water directly into the Old Well Stream at Outwell, and thence to the existing outfall at Wisbech. These significant engineering works appear to have been as 'part of the concerted action to replan the drainage of the Wisbech region', almost certainly by the Abbey of Ely within whose estate the new course lay (Hall 1987, pp. 46). The argument that the canalisation of the Nene along a new course was part of a strategy to establish a new market at Mercheforde thus seems less likely. The work appears to have been carried out in the early eleventh century before investments in market grants became commonplace, and there are good reasons to indicate that it may instead have been undertaken to protect from destruction by flood the contribution to monastic incomes of goods and profits derived from fenland grazing and other products.

The second topographical characteristic of new fenland towns, the establishment of a nodal intersection between road and river, was unfulfilled at Mercheforde. The settlement lies on the northernmost tip of a 'partly drowned peninsula' rising above the flat floor of the fenland basin (Hall 1987 , p. 38; OS 1985, 1986, 1988, 1999, 2000). Those areas of the peninsula that rise above the winter floodline ( $5 \mathrm{~m}$ above Ordnance Datum) provided a reliably dry archipelago of 'islands' for settlement and cultivation (Map 2). Below the $5 \mathrm{~m}$ contour, the degree of dampness of the lower areas of the peninsula varied with height above sea level along a continuum from mostly dry to permanently wet, encouraging the formation of peat. Mercheforde, on the northern part of that peninsula, was significantly isolated by the fen from the nearest dry ground in any direction except, of course, to the south. The hamlet of Coates in Whittlesey to the west, Wisbech to the north-west and the silt fens at Upwell to the north-east were each around $10 \mathrm{~km}$ away, while the nearest part of the Isle of Ely was over $15 \mathrm{~km}$ distant. The most feasible land-based route involved island-hopping from Mercheforde to Doddington across the intervening islands in the archipelago, and thence to Chatteris and Somersham; but there is no evidence that this route was any more than a track way in the medieval period, running for some distance along the bank of the Old West Water between Chatteris and Somersham (and fossilized in sections of the modern B1050) (Hall 1992, pp. 84, 94; OS $1999,2000)$. There was no network of major roads connecting the settlement to the other vills of the region, nor were there any substantial twelfth-century causeways like those between Stuntney and Ely, Willingham and Aldreth, or from Hemingford Grey to St Ives (which includes a spectacular stone bridge). There was no equivalent investment to link March with Wisbech, Outwell, Little Downham or with Coates; not even with Chatteris and Somersham. It is particularly significant that the seventeenth-century market was only established twenty-two years after Vermuyden and his labourers had dug and built the first and second Bedford Rivers - that is, when large-scale fen drainage for the first time permitted the construction of proper roads to Wisbech, Ely and Peterborough. Of course, there must have been some limited movement around medieval Mercheforde by foot and hoof along the silted beds of earlier watercourses, along river banks, and between atolls of drier ground. ${ }^{6}$ But such ways were localized, slow, only available in drier conditions, and mostly inaccessible to wheeled traffic (Darby 1974, pp. 105-7). They had little in common with the major medieval roads that led from Cambridgeshire and Suffolk into Ely or from Bedfordshire and Huntingdonshire into St Ives. They could not support Mercheforde in offering a regional intersection between traders travelling to the settlement by road and those arriving by water.

\section{Morphology}

Might morphological analysis of the settlement be more helpful? The planned layout of Mercheforde appears to have been fixed by c.1601-3 (CA R59.31.40.1; CUL Maps.bb.53(1).93.114-; Map 3). ${ }^{7}$ An estate map of that date is sufficiently detailed to record the boundaries of individual properties running in apparent ribbon development from west to east along the north bank of the Nene, and a single block of properties south of (and at right angles to) the river crossing. The boundaries of 
almost every one of those properties were still preserved in 1840 , and most remain readily identifiable on the Ordnance Survey map of 1900 (CA R51/28/1A-C; Map 4). Digital comparison of the seventeenth-century estate map with the tithe map of 1840 and the Ordnance Survey map of 1900 reveals the precision in the former's cartography (CA R51/28/1A-C). ${ }^{8}$ The layout of the settlement at Mercheforde thus remained more or less unchanged from about 1600 over the following three hundred years. Although the estate map shows that there were regular open spaces north and south of the river crossing in Mercheforde together with the ordered layout that might suggest a planned market, the difficulty remains in using a map of $c .1600$ to extrapolate the morphology of a mid-thirteenth century settlement.

The survival of an extent of Mercheforde made in 1251 goes some way towards illuminating that question (CUL EDR G3.27). The Ely Coucher Book, an account of the Bishop of Ely's manors in that year, records 90 messuages in Mercheforde, where single messuages usually paid an annual rent of $6 \mathrm{~d}$. and fractions of a messuage a closely proportionate amount (Appendix 1). The almost-universal consistency of the same annual rent for single messuages, and the careful pro-rata calculation of most fractional rents suggest that the area of each messuage was reasonably constant. The examples of Richard son of Ralph and Robert Clayland who each held two messuages for $12 \mathrm{~d}$., or Thomas son of Adam who held 5 messuages for $2 \mathrm{~s}$. $6 \mathrm{~d}$, illustrate the point. It is underscored by the holdings of men like Walter Spendlowe who held $1 / 4$ messuage for $1 \frac{1}{2} d$. and Richard son of Thomas who held $1 \frac{1}{3}$ messuages for $8 \mathrm{~d}$. The general conformity in the value of rents among the holdings might indicate that the holdings themselves were of roughly similar area.

The similarity between the regularity in the value of rents in 1251 and the properties mapped in c.1601-3 and 1840 is, of course, immediately apparent. That the single messuages of 1251 may indeed have been of a standardised area might be indicated by the tithe map, which shows that in 1840 properties along the north bank of the Nene tended to be around three-quarters of an acre in area, while those to the south of the river usually contained around $1 \frac{1}{2}$ acres (CA R51/28/1A-C). In 1840 larger properties were generally multiples of these units. Map 5, for example, shows a block of properties along the northern bank of the Nene where the areas of each of five properties conform reasonably well to 3 roods and 30 perches. ${ }^{9}$ To take just one example, the holding numbered 1860 on Map 5 contained 1 acre 3 roods and 20 perches, very close to twice 3 roods and 30 perches. If the layout of the town recorded by the early seventeenth century did in fact reflect the character of the settlement in 1251, then it might suggest a degree of regularity most commonly found in the formal planning of settlement.

There, however, the possibility of long-term persistence in the layout of the settlement from 1251 to 1601-3 might stall were it not for another coincidence between the data which allows the hypothesis of such continuity to be pursued. Both the order of the holdings in the thirteenth-century extent and the blocks of properties on the early seventeenth-century map present a syncopated appearance. Messuages in Mercheforde in 1251 were listed in a sequence of seven sets of standardised messuages (made up of 13, 10, 3, 8, 8, 12 and 20 holdings respectively) interspersed by small numbers of fractional messuages (both greater and larger than the standard holding). Similarly, the early seventeenth-century settlement was made up of a number of regular blocks of properties of apparently standardised area which were divided from each other by small numbers of properties irregular in shape and area. (The layout may be the result of attempts to reconcile a fundamentally regular system of land apportionment with minor meanders in the course of the river.) If the messuages in Mercheforde were listed clockwise from north-west to south (as was conventional practice), then the syncopated sequence of holdings in the 1251 extent can be overlaid with a fair degree of accuracy onto both the c.1601-3 map and that of 1840. The acreages recorded in 1840 provide a crosscheck for this hypothesis, demonstrating a fair degree of conformity with the standard and fractional holdings of 1251 (Map 6; Appendix 1). If these calculations are accurate, the layout of mid-thirteenth century Mercheforde appears to have remained largely unchanged into the mid-nineteenth century (and beyond) and bring us back to the possibility of insights into the 
morphology of medieval Mercheforde on the basis of the estate map of $c .1601-3 .^{10}$

The early seventeenth-century map indicates that there were two potential locations for a planned medieval market-place (Map 6). One lay immediately north of the bridge, framed by holdings to west and east and by pasture closes to the north. Another lay on the south side of the Nene immediately east of the approach to the bridge from the south. It was bounded to the west by the north-south route (running to the manorial centre at Doddington), to the north by the Nene, and to the south by the northern boundary of the block of messuages already mentioned. The eastern boundary had already been obscured by encroachment along the southern bank of the river.

At first sight this set of evidence is a hopeful development for the argument for a medieval market at Mercheforde. Called the 'hythe' in 1840, the area around the bridge was almost certainly used as a landing place for goods coming into and going out of the manor by boat from the middle ages onwards, and it is very likely that some of that activity was commercial. There was at least one shop in the vicinity by the later sixteenth century: in 1571 the churchwardens recorded that 'Robt Vandelowe hath hired the shoppe at the hyh bridge for $6 / 8$ to be paid to days before Ely fayer' (CA $\mathrm{P} 116 / 28 / 20)$. As the town is most likely to have received the shop as a bequest whose rents were intended to generate charitable income, the business there was probably reasonably profitable and perhaps one of a number around the bridge. Of interest in this context is the large messuage (rated as $1 \frac{1}{2}$ messuages) held by Peter le chapman in the 1251 , whose position within the list of holdings suggests that it stood towards the eastern end of the open space to the south of the bridge. If that interpretation is correct, the holding would have been well located for loading and offloading goods from the river.

But evidence for some commercial activity is not necessarily the same as evidence for a market. Neither open space was called a market before 1670, nor is there a record of a medieval market hall or cross on either site. Although the open area south of the bridge was the location of the new later seventeenth-century market, it does not appear to have had a market-related name two generations earlier. The estate map of $c .1601-3$ names it in three words: the first is indecipherable, the second two are 'Bridge Green'. The bridge was called 'hyh' bridge in 1571, and 'toun bridge' in 1582, and the strongest likelihood is that the open space was called 'High (or Town) Bridge Green' rather than 'Market Bridge Green' (CA P 116/28/20). The 'Green' suffix suggests that its origins lay in a planned communal amenity which may have included some informal trading - like the village greens of many upland settlements - rather than a market per se. The character of some of those activities were recorded in the churchwardens' accounts: in 1593, for example, 'the washing of shipe by straungers at the bridge is letten to Thomas Scottwill for iis for this yere and he to take no man above ijd for every skore' (CA P116/28/20).

The two remaining morphological characteristics of medieval markets - the orientation of roads and tracks on the new market place, and the presence of burgess plots - are equally unproductive for Mercheforde. The route leading northwards from the open space on the north side of the bridge appears originally to have meandered across a large area of open pasture. By c.1601-3 it was clearly subordinate to enclosures which had by then forced it into a number of changes of direction. If the track had been important, it is reasonable to infer that it would have dominated the alignment of new enclosures, rather than the other way around, and its insignificance in the landscape suggests that it did not lead to a central place like a market. South of the bridge, possibilities for any realignment of the route between the settlement and Doddington were tightly confined by the local topography. The block of properties south of the Nene lay on a narrow neck of higher ground between fen to both west and east (the former sufficiently deep to be called 'The Sumps'), so there was little leeway for movement in the orientation of the track (Wells 1830, Vol. 2, p. 204, citing Hayward's early seventeenth-century survey; CUL Maps.bb.53(1).93.114-).

While the alignments of roads and tracks in Mercheforde do not suggest that the open spaces performed any major market function in the middle ages, it might be argued that trade was instead 
focused on the canal which can be seen on the map of c.1601-3 and which ran along the entire frontage of the planned block to the south of the Nene. If this were the case, the messuages of this most southern block of holdings would have faced directly onto the trading space. However, although the canal (or, more strictly, the causeway along it) was called 'the hythe' by the nineteenth century, both it and the layout of this part of the settlement are straightforwardly explicable in terms of local geography. The block of holdings occupies a marginal situation at, rather than above, the winter flood-line and between two fairly deep areas of fen. These properties were particularly vulnerable to the risk of flooding: they lay too low to be predictably dry in winter and too close to areas particularly likely to collect water in time of inundation. It is significant, then, that the canal along the front of the properties has an exact double in another water-filled ditch which was still visible along the back boundary of the block in 1889 (Ordnance Survey Cambridgeshire Sheet XVI.5 $25^{\prime \prime}$ :mile). Both ditches were constructed at the boundary between fen and high ground, and the purpose of each was almost certainly to drain excess water from the settlement into the Nene as efficiently as possible; that is, to prevent the winter floods from reaching this block of holdings. Although the 'hythe' may not have been constructed for transporting goods, once it was there any property-holder would have been mad not to have made use of it to bring fen products and other goods as close as possible to his/her front door.

The presence of ordered freehold properties around new market-places is frequently cited as another indication of a medieval market, particularly where those occupying them were referred to as burgesses. However, although the messuages on each side of the bridge were undoubtedly planned holdings - of standard area with shared front and back boundaries - none of those on the southern or the northern banks of the Nene were laid out to face the regular open spaces which might be candidates for a market place, lying instead at right angles to them. Nor was anyone with a messuage in thirteenth-century Mercheforde called a burgess. It is unlikely that any tenants were in fact burgesses even if their surnames did not emphasis this status since almost all the holdings in Mercheforde were customary ('nat.', nativus) rather than free ('lib.' liber) in c.1601-3; burgesses tended to be freemen (Miller 1951, p. 150).

There is one further line of enquiry in the search for a medieval market in Mercheforde: if the settlement were primarily focused on commerce in 1251 one might expect to find more tenants with occupational surnames there than on the remainder of the estate. The population of the commercial centre at Ramsey, for example, generated more than 100 occupational surnames between the thirteenth and sixteenth centuries, while most people at the Bishop of Norwich's mid-twelfth century market port of King's Lynn were generally identified by the places from which they had come, their occupation or some personal characteristic (DeWindt \& DeWindt 2006, p. 114; Reaney 1967, pp. 37-58; Figure 1). The surnames of people of Mercheforde (and other parts of the Doddington estate) were quite different: there, most individuals were identified by surnames recording a family relationship, especially with a parent. That familial identifier suggests not only that most of the Bishop's tenants were born on the estate but also that the local community valued personal relationships more highly than any other attribute. In this, they had more in common with most rural communities across agricultural Cambridgeshire than with the inhabitants of contemporary market towns.

While Figure 1 also shows that there was a higher percentage of tenants with occupational surnames in Mercheforde in 1251 than on the remainder of the Bishop's Doddington manor, closer inspection suggests that this distinction may be more illusory than real. An analysis of the occupations pursued by thirteenth-century tenants in Mercheforde and Doddington suggests that the proportion of tenants in Mercheforde with occupational surnames indicating crafts and/or manufacture was very similar to that across the remainder of the estate (Figure 2). Nor were their occupations distinctively urban or even commercial; most could have been found in any rural community. Richard clayland (a plasterer), the soapmakers Henry and Wymark sapayn(e), and Gilbert le coverer (a roofer) could probably have made a living in most settlements. The presence of 
a market would, it is true, enhance profitable opportunities for almost any producer; but it was not essential for men whose principal income was derived from small building works or the production of daily necessities. It is more difficult to make this argument for two other tenants in Mercheforde William survel, perhaps a maker of savoury food, and Henry tympon, a drummer, who might indeed be heralded as indicative of a market function there. The problem in treating these men as active evidence for a market at Mercheforde is that men with similarly non-agricultural specialisms held land elsewhere on the Doddington estate where no market has been suggested. Alexander wynter (vintner) was part-holder of a cottage in Merche; the burgeys (burgess) family were fishermen, also with a cottage in Merche and a few newly-assarted acres there; there were two boatmen - William le botsler (boatman) was a censuarius with 55 acres in Doddington, and Richard le flotiere held a messuage at Benwick; a plasterer, Geoffrey le claver, was also a censuarius in Doddington, while Robert slaner, perhaps a weaver, held a fishery there (CUL EDR G3.27; Reaney 1967, pp. 55, 180, 184,208 ; Stratmann 1891, p. 229; Latham 1965). The point is underscored by the case of Geoffrey blancgernon, one of the Bishop's free tenants, who held Oswaldegrave in Doddington in 1251 for $1 / 2 \mathrm{lb}$. cumin to be paid each year at Easter. He held no land in Mercheforde (CUL EDR G3.27). In 1294 a man with the same name was accused of forestalling - that is, of intercepting merchants on the way to Ramsey market, buying their goods more cheaply than they would have sold for there, and selling them on at a profit (DeWindt \& DeWindt 2006, p. 165). We cannot be sure that both references are to the same man, of course, or whether Geoffrey (if it was indeed he) had acquired a holding in Mercheforde in the intervening 40 years. If there is any connection between this incomplete and tantalising pair of records, then it may just mean that at least one trader did not think that a messuage in Mercheforde was an essential prerequisite for his business.

There is, then, little to support the contention that the origins of Mercheforde can be found in the establishment of a planned market along the Nene, or even in the gradual movement of population towards informal trading activity there. There is no evidence for the foundation of a medieval market there, nor for its role as a medieval centre for trade. It might be argued that Mercheforde is an example of a failed medieval market, but this seems to me to compound the difficulties, since it would involve acceptance of a foundation for which there is no evidence, of at least some market activity for which there is no evidence, and of a disappearance, for which there is also no evidence (as in 'there was a market here once'). That is, only the 'universal truth' based on settlement morphology would be held to be sufficient justification for that interpretation.

The remainder of this paper offers an alternative proposition: that the planned, medieval foundation at Mercheforde may have been established by the Bishops of Ely as a strategy for maximising income from rents in a restricted geographic location. An analogy can be found in rural industrial estates which can produce good income in rents for modern farmers: the loss to agricultural exploitation of a relatively low acreage of land is compensated several, or even many, times over by rental income. That proposition is explored in five ways: the geography of the settlement; the status of holdings in Mercheforde; patterns of landholding across the Doddington estate in 1251; the benefits to peasants from common rights across the fens; and benefits to the Bishop from rents.

\section{Exploring other explanations for Mercheforde's origins}

The thirteenth-century messuages in Mercheforde mostly lay on planned plots. If they were not laid out as burgess plots, why were they laid out in this way and on such a scale? It is clear from the large number of messuages, all of which were occupied in 1251, that there was a substantial demand for customary tenancies of this kind. The geography of the archipelago meant that there were few locations within the Doddington manor on which new villages of any size could be planted in order to meet such a need: the dry-land sites secure from the risk of winter flooding had been fully occupied by existing settlements for centuries. There were, however, other parts of the surrounding peninsula which, although they lay at the floodline, carried a narrow gravel cap. If settlement were 
restricted to that narrow corridor of gravel, the risk of flooding on these well-drained 'hards' might be mitigated in ways with which fenland husbandmen were already familiar - that is, by constructing catchwater drains. Upcast from the excavation of the new river channel lying on top of land already more or less along the flood line offered a further narrow shelf for settlement along the northern bank of the Nene. A planned foundation at Mercheforde may have enabled the Bishops to maximise occupation in a landscape in which opportunities for settlement were severely limited and in which there were large numbers of men eager to take up non-arable holdings (Miller 1967, p.108).

This does not, however, explain the anomalous 'messuage' status of Mercheforde holdings: unlike most messuages, no customary arable was attached to them. This does not appear to be simply a lacuna in the documentary evidence: extensive fieldwalking during the fenland project around the settlement found 'no evidence of medieval strips', and the settlement does not appear to have been endowed with any arable land (Hall 1987, p. 47). A rent of 6d. per year appears to have brought each tenant only the house and the acre or so of toft on which it stood. Why were these holdings not referred to as coteria instead? Miller defined cottagers as 'men with a mere acre or so who could not have subsisted entirely on their land' and while it is true that many cotlands were smaller than this, others were not: Adam unwyne's cottage at Willingham, for example, came with two acres, while that of Nicholas son of Adam at Little Downham contained an acre (Miller 1951, p. 137; Smail 1968; CUL EDR G3.27).

Their status as customary holdings rather than rent-paying censuarii is as puzzling. Miller has commented that villein status was distinguished by the character rather than the volume of services required of customary tenants, especially regular labour (Miller 1951, p. 137, also 141). Yet the tenants of Mercheforde did not owe week work or carrying duties, nor were they subject to putting their sheep in the lord's fold. In fact, they owed remarkably few customary payments or services: they attended only the 'great harvest boon' at Doddington, and paid just the most general dues tallage, leyrwite, gersuma and twice their rent for relief and heriot. Even some of the hundredors and all the censuarii on the estate were required to provide some labour services, and to undertake carrying duties (CUL EDR G3.27). Despite their customary status, only the most general responsibilities were attached to the Mercheforde messuages.

Such ambiguities might, perhaps, be explained as the consequence of the commutation of villein or cotland services for a money rent. The complete absence of customary arable from the messuages suggests, however, that an origin as villein holdings is unlikely; and if these were commuted cotland services, then they would be more likely still to have been called coteria rather than messuages. Moreover, cotlands in Merche to the south held by quite different rents and conditions: not only did they generally pay an annual rent of around $12 \mathrm{~d}$. as well as customary payments like bridgesilver and cranesilver, they also had to perform 'the same [labour] customs as the holder of a full land' (CUL EDR G3.27, my addition). Yet the messuages in Mercheforde paid only 6d. per year, without any customary payments, and owed none of the customs of villeins with full or half holdings or even of cottagers. Their lower rents and light responsibilities seem unlikely to have originated in commutations.

The messuages in Mercheforde might alternatively be interpreted as the result of a large-scale, planned assart in the higher parts of the fen. But they were not described as purpresturae or as nova terra in 1251, nor were their tenants described as 'newly (or recently) enfeoffed' or enfeoffed 'in the time of' an earlier Bishop, even though there is good evidence for the scrupulous application of these terms to thirteenth-century assart in other parts of the Bishop's Doddington estate (Miller 1951, pp. 110, 119). Thirty-four new holdings at Cuniwode (just west of the medieval hamlet at March), for example, were described as 'enfeoffed' in 1251; furthermore, unlike the messuages in Mercheforde, they were remarkably varied in area, ranging from $1 \frac{1}{4}$ roods to 12 acres (CUL EDR G3.27). The evidence of only very limited reclamation in the landscape of Doddington, and the marked focus of that activity in the south of the estate, appears to confirm the documentary evidence. There is nothing in the landscape of Mercheforde that demonstrates similar characteristics 
to the fen-edge reclamations identified in the peat fens at Burwell or Apesholt in Littleport, or the extensive reclamations in the silt fens around Wisbech and Spalding (RCHM 1972, pp. liv-Ixii; Hall 1992; Silvester 1988; Hallam 1965). There is nothing, then, to suggest that Mercheforde originated as assart.

The most significant attribute of the messuages in Mercheforde was that they had full rights of common and intercommon in the manor (CA 606/M2 and 606/M9). ${ }^{11}$ Rights of common pasture on the Doddington estate allowed almost unlimited grazing on some of the richest fenland in the region. The medieval vill (including Doddington and its hamlets at Wimblington, Benwick and March) was one of the largest in the country, extending over nearly 38,000 acres $(15,323$ ha.) of which most was fen pasture and meadow. Beyond the vill, the Bishop's customary tenants had rights of intercommon across a vast area whose boundaries ran from Upwell to Littleport and Little Downham, past Somersham and Ramseymereside to King's Delph, along the Catswater to Singlesole, Throkenholt and Tydd, and then along the Old Well Stream from Wisbech back to Upwell (Map 1; Pugh 1953, p. 110; Hall 1987, p. 38). Individual common rights could further be enriched by jointstock negotiations with the manor for control of large areas of grazing by discrete groups of tenants and this was certainly a strategy pursued by the men of Mercheforde in 1251 . With the tenants at Merche, they held 'newly 360 acres of fen and 20 acres de pollote by charter for 60 s. in equal payments; and also 64 acres of fen next to Idenhe ${ }^{12}$ for 20s. $8 \mathrm{~d}$. in equal payments; and 40 acres of fen in Elnesorchard ${ }^{13}$ for 7s. 2d. in equal payments' (CUL EDR G3.27). Acting on their own, the Mercheforde tenants held a further ' 188 acres of fen next to Upstavendik ${ }^{14}$ for $23 \mathrm{~s}$. $6 \mathrm{~d}$. in equal payments' (ibid.). ${ }^{15}$

Rights of common were conventionally attached to 'all tenants of ancient arable' but, as we have seen, no arable, ancient or otherwise, was included with the messuages in Mercheforde (Neilson 1929, p. 732 and 1920, p. Ixxvi). Perhaps the point of defining the holdings at Mercheforde as messuages rather than cottages may have been to provide them with the status which brought with it rights of common grazing across thousands of acres in the western fen basin as if they were conventional customary holdings? Was this the prize in which there was evidently so much peasant interest - as modern marketers might say, their 'unique selling point'?

The possibility that access to common rights of grazing may have been an important motive for men seeking messuages in Mercheforde may explain the high proportion of tenants there with family surnames. Figure 3 suggests that families on the Doddington estate saw in messuages at Mercheforde an opportunity to diversify their land holdings: by far the largest number of tenants with family surnames were either individuals with a portfolio of landholdings across the manor or were representatives of extended families with collective property interests (cf. Miller 1951, p. 148). Of the latter, men with no other holdings on the estate, and who had siblings and parents living elsewhere in the vill, may have been the younger sons 'of a prosperous peasantry' who might otherwise have struggled to make a living (Miller 1951, p. 98). Yet four of the eleven family groupings included jurors, men almost certainly among the better-off in their communities and, perhaps, looking for investment opportunities (DeWindt 1991, p. 628). Figure 4 shows the character of these mixed bags of holdings. Thomas, son of Adam, to take one example, held a messuage in Mercheforde, while his brothers held three fisheries on the estate, some hundredal acres in Doddington and Wimblington ${ }^{16}$, a censuarial messuage at Doddington, a full villein holding at Wimblington and a part-share in another, and a number of small plots of censuarial land in Cuniwode and Wimblington. They were almost certainly the sons of Denise, widow of Adam, who held a censuarial messuage at Doddington and a few assarted acres in Cuniwode and Wimblington. These men were not defined by the status of the land they held: they were clearly as happy to hold freely as to take on land with full customary services. Their primary focus appears to have been the construction of a range of landholdings which together maximised access to as wide a range of rich fenland resources and economic opportunities as was locally possible (Dodwell 1944, p. 170).

The wealth of the fenland landscape was a truism by the twelfth and thirteenth centuries. Ely was 
'praiseworthy for its woods, vineyards and waters, exceedingly rich in all fruit, livestock-breeding and crops .. richer than average in its pasture for cattle and horses' and 'a productive breedingground for farm animals and beasts of burden' (Fairweather 2005 ed., p. 213); the marshes at Thorney 'abound in trees, whose smooth height stretches towards the stars. The plain there is as level as the sea; which with its grass flourishing delights the eye, and which is so smooth that there is nothing to hinder him that runs through it'; and at Ramsey there were 'fair gardens, rich pastures, shady groves, and rich meadows; which in the spring time look most beautiful' (Darby 1974, p. 53-4). The value of the peat fens lay in their non-arable products.

The most important crop was grass: pastures flooded in winter produced rich 'whiteseed' grass ('fen hay') which could be mown twice each year, its productivity and quality underpinned by the winter flooding which made them natural watermeadows (provided that the water did not linger too long). By the thirteenth century the rental value of an acre of fen meadow, or the lactage from a single cow grazing upon it, could bring in three times or more income than an acre of arable land, stimulating a two- or three-fold increase in the the acreage of meadowland in the fen and along the fen between the mid-eleventh and the mid-fourteenth centuries (Campbell 2000, p. 146; Raftis 1957, pp. 153,157; Darby 1974, p. 67). ${ }^{17}$ Even in the early nineteenth-century it was still meadows and pasture which produced the greatest returns for fenland farmers (Gooch 1811, p. 179). By the time records become more frequent in the mid-twelfth century, the peat fens were supporting such large numbers of cattle that they were customarily and vividly recorded as grazing 'horn under horn' (Neilson 1920, pp. xxxviii, xliii, xlix; Miller 1951, p. 80; Darby 1974, pp. 66, 68, 77-8). Annual roundups involved enormous numbers of beasts: a contemporary muster on 'la Est fen' in Lincolnshire involved so many animals that it took three days and required 'a bailiff, and twenty-two men' (Neilson 1920, p. xiii). The vaccary of the Bishop of Ely at Doddington held at least 100 cows and 5 bulls in 1251, while there were more than 1,200 cattle in total across the early fourteenthcentury estate of the Abbey of Peterborough (Miller 1951, p. 79; Biddick 1989, p. 81). The central role played by cattle in the economy of the peat fens was not based on breeding or the production of meat or leather, but on cheese and butter from dairying (Biddick 1989, p. 96; Campbell 2000, pp. 135-145; Darby 1974, p. 66). The demesne herd at the Crowland manor at Cottenham, for example, produced one 51/2lb cheese each day between 7 May and Michaelmas 1280-1281, and twelve stones of butter in 1288-9, adding significance to the customary duty of the men of Merche in 1251 to take a 'boatload of cheese' to King's Lynn each year (Ravensdale 1974, pp. 59-60; CUL EDR G3.27). ${ }^{18}$

The significant contribution of the fen to the local economy of fenland manors meant that 'in no part of England were common rights more important' (Darby 1974, p. 68; Neilson 1920, pp. xxxiv-xliii). Medieval and early modern peasants with access to fen pasture and other fen produce were able to exploit the same opportunities as their manorial lords, and tended as a result to be significantly better off than their upland counterparts (Darby 1974, pp. 22-38; Thirsk 1953, pp. 40-45; Spufford 1974, pp. 131-34). A man with little arable land but with a right of common in fen grazing and other products could live very well, often better than an upland peasant with thirty acres of arable land: at Waterbeach in 1340, for example, even 'men with little or no land could support themselves through their rights over the extensive common pastures and fens' (Wright \& Lewis 1989, p. 250). Part of the reason could be found in the profits from dairying. Freemen and customary tenants were as keen cattlemen as their manorial lords; for example, at about 4.5 cows per taxpayer, peasant cattle herds in the Liberty of the Abbey of Ramsey in 1291 were twice the size of those of their upland contemporaries, while almost every thirteenth-century Ramsey tenant owned at least one cow (Postan 1973, pp. 230, 245). That pattern appeared unchanged along the fen edge in the late sixteenth century when Ravensdale concluded that 'the keeping of cattle was almost universal among the peasantry' and seventeenth-century commoners of Cottenham still grazed over 2000 dairying cattle on their fens (1974, 62; see also Fortrey 1685, p.59 and Spufford 1974, pp. 131-133). ${ }^{19}$ Dairying income could be augmented within the parish boundary by other rights of common to fish, fowl, peat, reeds, sedge, osiers and other fen products. 
Messuages in Mercheforde thus offered the prospect for individuals as well as extended families, generally already established within the Bishop's Doddington manor, to exploit new or additional rights of common pasture across extensive fenland pastures, where even those otherwise landless might achieve a reasonable standard of living. That these benefits were attractive to thirteenthcentury fenmen is suggested by the large size of the settlement, its planned layout and - despite the substantial number of messuages - the absence of unoccupied holdings in 1251 . Together they indicate a high degree of demand for holdings there.

The benefit to the Bishop lay in the substantial annual rents from the holdings at Mercheforde that accrued to his estate: $£ 2.5 \mathrm{~s} .91 / 2 \mathrm{~d}$. (CUL EDR G3.27). He may well have calculated that, per acre, income from these rents was likely significantly to outstrip his income from grazing of the same area, whether directly managed from the demesne or leased to tenants. The attractiveness of the sum can be gauged by comparison the rents received from the farm of the Bishop's market and fair at Wisbech in 1251 where the tolls of the market were let at 50s. a year, while those for the fair brought in an additional 20s. (CUL EDR G3.27). The farm of the tolls of Wisbech market brought in just 5 s. per year more than the rents at Mercheforde.

\section{Conclusion}

The large number of planned messuages in Mercheforde attracted a range of constituencies. On the one hand they may have offered the chance of an established occupation and a reasonably reliable income to a growing, frequently landless, population of younger sons from the Doddington estate and beyond; on the other, they seem to have enabled extended families and more affluent individuals to broaden portfolios of existing free and customary landholdings, small assarts, and fisheries. There did not need to be a medieval market at Mercheforde to justify its existence: the access to one of the largest and richest areas of wetland grazing in England provided by rights of common attached to its messuages was more than sufficient.

The extent of the planned settlement, the consistency of the rents, and their standarised status and rights all suggest that the idea of establishing a substantial, new settlement at Mercheforde was implemented within a relatively short period of time. A planned layout provided an efficient framework for settling large numbers of tenants in a location where the availability of land suitable for occupation was very limited. It is, then, no wonder that Mercheforde had the appearance of an urban development since new market towns shared the same requirements: the establishment of a reasonably large population of tenants of equal status within a reasonably confined area. In the case of the latter, proximity to a market place was essential; in the case of the former, there was a paucity of land on which settlement on this scale could be achieved. Yet they shared a common principle: in both cases, lords released a relatively small acreage from agricultural use and recouped the consequent loss of crops many times over through rents. In Mercheforde, local geographic constraints provided a context within which creative and entrepreneurial Bishops of Ely might extend their manorial incomes by applying old lessons learned in the establishment of new market towns to new conditions for establishing other large settlements through which new sources of rental income could be exploited.

Perhaps a codicil might be added to the 'universal truth' which Beresford and Taylor have so powerfully established, that planned settlements were usually laid out for commercial purposes. Most cases were probably aimed at the establishment of a centre for trade, but in some places (like Mercheforde) economic activity might be expressed in some other way. Either case would satisfy the general incentive for manorial lords: investment of a relatively small area of land in a planned settlement from which substantial profits from rents (and, sometimes, tolls) might be expected. Provided that the inhabitants of a new foundation could make a good living and thus pay good rents, 
how important was it really to lords how that living was made?

\author{
Dr Susan Oosthuizen FSA \\ University of Cambridge Institute for Continuing Education \\ Madingley Hall \\ Madingley \\ Cambridge CB23 $1 \mathrm{HN}$ \\ Email:smo23@cam.ac.uk
}

\title{
Acknowledgements
}

This paper owes an enormous debt to discussions and debates with Mr Christopher Taylor to whom many improvements and insights are owed; the mistakes and misconceptions that remain are all the author's own. Mr David Edwards was generous enough to provide a copy of his transcript of Rev Walker's note on the date of origin of the early seventeenth-century estate map. Mrs Edna Stacey at March Museum was kind enough to allow access to the Museum's photostat copy of the estate map, which is printed in greater contrast (and thus shows more detail) that those in the Cambridge University Library and the Cambridgeshire Archives.

\section{MANUSCRIPT SOURCES}

\section{Cambridgeshire Archives}

606/M2 March, Bylaws 1679, and Orders concerning commons 1669-70.

606/ M9 March, Decree 166,9 copy 1766.

P116/28/19-20 March, late 19th-century transcription of copies of documents relating to March 1222 - 16th-century.

R51/28/1A-C March, Tithe Map and Schedule 1840.

R52/24/31 Jonas Moore circa 1706: Mapp of ye Great Levell of ye Fenns extending into ye Covntyes of Northampton, Norfolk, Suffolke, Lyncolne, Cambridg[e] and Huntington and the Isle of Ely as it is now drained, described by, Sr. Jonas Moore. Svrveyr. Genl.

R59/31/40/1 Hand-drawn and coloured copy of William Hayward's 1604 map of the fens, by R. Peylor Smyth 1727.

R59/31/40/176 Printed copy of William Hayward's 1604 map of the fens, by T. Badeslade, 1727.

Smail, R. C., 1968. Ely Coucher Book, Extract of that part relating to Willingham, Unpubl. Ms. 
Map of Doddington, Wimblington and March c.1601-3 Photostat copy made in 1939 from an original, now mislaid, then in the ownership of March District Council.

\section{Cambridge University Library}

EDR.G3.27

Ely Coucher Book, 1251

Maps.bb.53(1).93.114- Map of Doddington, Wimblington and March c.1601-3 Photostat copy made in 1939 from an original, now mislaid, then in the ownership of March District Council.

\section{Mr David Edwards}

Walker, C. E., 1894. 'An Old Manor Map', transcription by David H. Edwards, 2007.

\section{March Museum}

Map of Doddington, Wimblington and March c.1601-3, Photostat copy made in 1939 from an original, now mislaid, then in the ownership of March District Council.

\section{PRINTED PRIMARY SOURCES}

Anonymous, c. 1646. The Anti-Projector, or a History of the Fenland Project (Cambridge University Library, British Library microfiche, B125, 2 9, Reel 1348,8).

British Geological Survey 1:50 000, Ely, Sheet 173, 1980. BGS, Nottingham.

British Geological Survey, 1:50 000, Peterborough, Sheet 158, 1984. BGS, Nottingham.

British Geological Survey 1:50 000, Ramsey, Sheet 172, 1995. BGS, Nottingham.

British Geological Survey 1:50 000, Wisbech, Sheet 159, 1995. BGS, Nottingham.

Fairweather, J. (ed.), 2005. Liber Eliensis (Woodbridge).

Fortrey, S., 1685. The History or Narrative of the Great Level of the Fenns called Bedford Level (London).

Gibbons A. (ed.), 1891. Ely Episcopal Records (Lincoln).

Gooch, W., 1811. General View of the Agriculture of Cambridge (London).

Ordnance Survey, 1988. Pathfinder 920. March. 1:25 000 (Southampton).

Ordnance Survey, 1889. March. Cambridgeshire Sheet XII: 1, 3. 25" : mile (Southampton).

Ordnance Survey, 1985. Pathfinder 899, Wisbech (South). 1:25 000 (Southampton).

Ordnance Survey, 1986. Pathfinder 919, Whittlesey \& Area. 1:25 000 (Southampton).

Ordnance Survey, 1999. Explorer 225, Huntingdon and St Ives, 1:25 000 (Southampton).

Ordnance Survey, 2000. Explorer 226, Ely and Newmarket, 1:25 000 (Southampton).

Ordnance Survey, 1889. March. Cambridgeshire Sheet XVI: 5. 25" : mile (Southampton).

Ordnance Survey, 1900. March. Cambridgeshire Sheet 16.01. Scale $1: 4340$ (Southampton).

Wells, S., 1830. The History of the Drainage of the Great Level of the Fens, called the Bedford Level (London). 


\section{SECONDARY SOURCES}

Barley, M., ed., 1975. The Plans and Topography of Medieval Towns in England and Wales (York).

Beresford, M., 1988. ed. New Towns of the Middle Ages (Stroud).

Beresford, M. \& St Joseph, J. K., 1979. Medieval England (Cambridge).

Biddick, K., 1987. 'Missing links: taxable wealth, markets, and stratification among medieval English peasants', Journal of Interdisciplinary History, 18, 2, pp. 277-298.

Biddick, K., 1989. The Other Economy. Pastoral Husbandry on a Medieval Estate (Berkeley).

Britnell, R., 1992. The Commercialisation of English Society 1000-1500 (Cambridge).

Campbell, B., 2000. English Seigniorial Agriculture, 1250-1450 (Cambridge).

Darby, H. C., 1974. The Medieval Fenland (Newton Abbott).

DeWindt, A., 1987. 'Redfining the peasant community in medieval England: the regional perspective', Journal of British Studies, 26, pp. 163-207.

DeWindt, A., 1991. 'Local government in a small town: a medieval leet jury and its constituents', Albion, 23, 4, pp. 627-654.

DeWindt, A. \& DeWindt, E., 2006. Ramsey. The Lives of an English Fenland Town (Washington DC).

Dodwell, B., 1944. 'The free tenantry of the hundred rolls', Economic History Review, 14, 2, pp. 163171.

Hall, D., 1987. 'Fenland project, number 2: Cambridgeshire survey Peterborough and March', East Anglian Archaeology, 35.

Hall, D., 1992. 'Fenland project, number 6: The south-western Cambridgeshire fenlands', East Anglian Archaeology 56.

Hall, D., 1996. 'Fenland project, number 10: Cambridgeshire survey, Isle of Ely and Wisbech', East Anglian Archaeology 79.

Hallam, H. E., 1954. The New Lands of Elloe (Leicester).

Hart, C. R., 1965. Early Charters of Eastern England (Leicester).

Haslam, J., ed., 1984. Anglo-Saxon Towns in Southern Englan ( Chichester).

Harvey, P. D. A., 1965. A Medieval Oxfordshire Village, Cuxham 1240 to 1500 (Oxford).

Hodges, R. \& Hobley, B., eds., 1988. The Rebirth of Towns in the West AD700-1500 (York,).

Howell, C., 1983. Land, Family and Inheritance in Transition, Kibworth Harcourt 1280-1700 (Cambridge).

Jones, E., 2000. 'River navigation in medieval England', Journal of Historical Geography, 26, 1, pp. 6082.

Langdon, J., 1993. 'Inland water transport in medieval England', Journal of Historical Geography, 19, 1, pp. 1-11.

Langdon, J. 2007. 'The efficiency of inland water transport in medieval England', in Waterways and Canal-Building in Medieval England, ed. J. Blair (Oxford), pp. 110- 130.

Latham, R. E., 1965. Revised Medieval Latin Word-List (London).

Letters, S., 2003. Gazetteer of Markets and Fairs in England and Wales to 1516. http://www.history.ac.uk/cmh/gaz/gazweb2.html, accessed May 2012. 
Miller E., 1951. Abbey and Bishopric of Ely ( Cambridge).

Neilson, N., 1920. A Terrier of Fleet, Lincolnshire (London).

Neilson, N., 1929. 'English manorial forms', American Historical Review, 34, 4, pp. 725-739.

Onions, C. T., ed., 1973. The Shorter Oxford English Dictionary OED, (Oxford).

Oosthuizen, S., 2012. 'Rural settlement and commerce in the medieval peat fen, c.900-1300', in Rural Medieval Britain and Ireland, AD 800-1600: settlements, landscapes and region, ed. P. Stamper and N. Christie (Oxford), pp. 206-224.

Page, F. M., 1934. Estates of Crowland Abbey, A Study in Manorial Organization (Cambridge).

Page, W., Proby, G. \& Inskip Ladds, S., eds. 1936. Victoria County History of Huntingdonshire, Volume 3 (London).

Postan, M. 1973. 'Village livestock in the thirteenth century', in Essays on Medieval Agriculture and the Problems of the Medieval Economy, ed. M. Postan (Cambridge), pp. 214-248.

Pugh, R. B., ed., 1953. Victoria County History of Cambridgeshire and the Isle of Ely, Volume 4 (Oxford).

Raftis, J. A., 1957. The Estates of Ramsey Abbey; a study in economic growth and organization (Toronto).

Ravensdale, J., 1974. Liable to Floods (Cambridge).

Reaney, P. H,. 1943. Place-names of Cambridgeshire and the Isle of Ely (Cambridge).

Reaney, P. H., 1967. The Origin of English Surnames (London).

Royal Commission on Historic Monuments, 1972. North-East Cambridgeshire (London).

Schofield, J. \& Palliser, D., eds. 1981. Recent Archaeological Research in English Towns (York).

Siddle, D. J,. 1967. The rural economy of medieval Holderness', Agricultural History Review, 15, 1, pp. 40-45.

Silvester, R., 1988. 'The fenland project number 3. Norfolk survey: Marshland and the Nar Valley', East Anglian Archaeology 45.

Spoerry, P., Atkins, R., Macaulay, S. \& Popescu, E., 2008. 'Ramsey Abbey, Cambridgeshire:

Excavations at the site of a fenland monastery', Medieval Archaeology, 52, pp. 171-210.

Spufford, M., 1974. Contrasting Communities (Cambridge).

Stone, D., 2005. Decision-Making in Medieval Agriculture (Oxford).

Stratmann, F. H., 1891. A Middle English Dictionary (Oxford).

Taylor, C. C., 1973. The Cambridgeshire Landscape (London).

Taylor, C. C., 1982. 'Medieval market grants and village morphology', Landscape History, 4, pp. 21-8.

Taylor, C. C., 1995. 'Reach, Cambridgeshire: A medieval fen-edge port and market', in East Anglian Studies, eds. A. Longcroft \& R. Joby (Norwich), pp. 267-275.

Thirsk, J., 1953. Fenland Farming in the Sixteenth Century (Leicester).

Walker C. E., 1909. Records of a Parish (March).

Wright, A. P. M. \& Lewis, C., eds., 1989. Victoria County History of Cambridgeshire and the Isle of Ely, Volume 9 (Oxford). 


\begin{tabular}{|c|c|c|c|c|c|}
\hline $\begin{array}{l}\text { Tenant name, listed in } \\
\text { same order as in } 1251\end{array}$ & Size of holding 1251 & Rent in 1251 & $\begin{array}{l}\text { No. on } 1840 \\
\text { tithe map }\end{array}$ & $\begin{array}{c}\text { Area on } 1840 \\
\text { tithe map (acres) }\end{array}$ & Notes \\
\hline \multicolumn{6}{|c|}{ NORTH BANK OF THE NENE FROM WEST TO EAST } \\
\hline Richard son of Ralph & 2 messuages & $12 d$ & $1874-5$ & n.k.+0.2.23 & \\
\hline John de Beynwick & 1 messuage & $6 d$ & 1873 & 0.2 .25 & \\
\hline Henry son of Elena & 1 messuage & $6 d$ & & & \\
\hline Henry son of Walter & 1 messuage & $6 d$ & 1872 & $0.3 .13+n . k$ & \\
\hline Godlomb son of Aylmer & 1 messuage & $6 d$ & & & \\
\hline Reginal clerk & 1 messuage & $6 d$ & & & \\
\hline Ralph powe & 1 messuage & $6 d$ & n.k. & n.k. & \\
\hline Thomas son of Adam & 5 messuages & $2 s 8 d$ & $1870-1$ & N.k.+1.2.14 & \\
\hline \multicolumn{6}{|c|}{ Sub-total: 13 standard messuages ${ }^{1}$} \\
\hline Robert de Estworth & $1 / 2$ messuage & $3 d$ & ? 1868-9 & n.k. & \\
\hline \multicolumn{6}{|c|}{ Sub-total: 1 irregular messuage } \\
\hline Aldus Tholi & $\begin{array}{c}1 \text { messuage } \& \text { a } \\
\text { languetta }^{2}\end{array}$ & $7 d$ & 1867 & 0.3 .14 & \\
\hline John bule & $\begin{array}{l}1 \text { messuage \& a } \\
\text { languetta }\end{array}$ & $7 d$ & 1866 & 0.3 .29 & \\
\hline Thomas de Walsokne & $\begin{array}{l}1 \text { messuage \& a } \\
\text { languetta }\end{array}$ & $7 d$ & 1865 & 0.3 .35 & \\
\hline Richard son of Hugh & $\begin{array}{l}1 \text { messuage \& a } \\
\text { languetta }\end{array}$ & $7 d$ & 1864 & 0.3 .16 & \\
\hline Richard his brother (sic) & $\begin{array}{l}1 \text { messuage \& a } \\
\text { languetta }\end{array}$ & $7 d$ & 1863 & 0.3 .0 & \\
\hline \multicolumn{6}{|c|}{ MARYLEBONE LANE } \\
\hline Stephen de Stratham & $\begin{array}{c}1 \text { messuage \& a } \\
\text { languetta }\end{array}$ & $7 d$ & 1860 & 1.3 .2 & $\begin{array}{l}2 \times \text { standard } \\
\text { messuages }= \\
1.2 .2 \text { acres }\end{array}$ \\
\hline Richard de Westreye & $\begin{array}{l}1 \text { messuage \& a } \\
\text { languetta }\end{array}$ & $7 d$ & & & \\
\hline Robert schad & $\begin{array}{l}1 \text { messuage \& a } \\
\text { languetta }\end{array}$ & $7 d$ & 1859 & 0.2 .11 & \\
\hline Henry Chaumperneys & $\begin{array}{l}2 \text { messuages \& } 2 \\
\text { languettae }\end{array}$ & $14 d$ & $1855^{3}-8$ & $\begin{array}{c}0.0 .37+ \\
0.2 .38+0.3 .34\end{array}$ & \\
\hline
\end{tabular}

\footnotetext{
${ }^{1} 13$ properties are shown in this block on the estate map of c.1601-3. Where the correlation between the 1251 and the Tithe apportionment seems incomplete in this Appendix, the attribution of messuages to a geographic location is consistently confirmed by the early seventeenth-century estate map which shows that the appropriate number of properties can be located in the particular block to which they are attributed here, The accuracy of the cartography of the estate map has been confirmed in the accuracy with which it can digitally be overlain on both the tithe map. And the 1900 OS map

${ }^{2}$ A languetta is a tongue of land. The possibility that these might be the narrow frontages on the river bank between the messuages and the Nene was investigated, but there is little evidence that this was the case. It is more likely that they were narrow strips of land in the fen, ditched on both sides.

${ }^{3}$ Plot number 1855 was a narrow block of river frontage measured at 37 perches in 1840.
} 


\begin{tabular}{|c|c|c|c|c|c|}
\hline \multicolumn{6}{|c|}{ Sub-total: 10 standard messuages } \\
\hline Walter spendelowe & $1 / 4$ messuage & $1 \frac{1}{2} d$ & & & \\
\hline \multicolumn{6}{|c|}{ Sub-total: 1 irregular messuage } \\
\hline \multicolumn{6}{|c|}{ ROOKS LANE } \\
\hline $\begin{array}{l}\text { Robert de Hedele \& } \\
\text { Geoffrey nosey }\end{array}$ & 1 messuage & $4 d$ & & & \multirow{3}{*}{$\begin{array}{l}\text { These } \\
\text { properties } \\
\text { formed a } \\
\text { single } \\
\text { coherent } \\
\text { block in } 1601 \text { - } \\
3 \text { and } 1840\end{array}$} \\
\hline $\begin{array}{l}\text { Christiana munek \& } \\
\text { Richard le convers' }\end{array}$ & 1 messuage & $6 \mathrm{~d}$ & 1853 & 2.2.29+n.k. & \\
\hline Avice daughter of David & 1messuage & $6 d$ & & & \\
\hline \multicolumn{6}{|c|}{ Sub-total: 3 regular messuages } \\
\hline Dick Gase & $1 / 2$ messuage & $3 d$ & & & \\
\hline \multicolumn{6}{|c|}{ Sub-total: 1 irregular messuage } \\
\hline William butler & 1 messuage & $6 d$ & & & \\
\hline John clericus & 1 messuage & $6 \mathrm{~d}$ & & & \\
\hline Peter son of Thomas & 1 messuage & $6 d$ & 1852 & 0.3 .23 & \\
\hline Dawe spendelowe & 1 messuage & $6 d$ & $1849-50$ & 0.3 .14 & \\
\hline Stephen Gase & 1 messuage & $6 d$ & $1847-8$ & 0.2 .23 & \\
\hline John son of Hugh & 1 messuage & $6 d$ & 1846 & 0.2 .28 & \\
\hline Everard Gase & 1 messuage & $6 d$ & 1845 & 0.3 .30 & \\
\hline Dave spendelowe & 1 messuage & $6 d$ & 1844 & 0.3 .33 & \\
\hline \multicolumn{6}{|c|}{ Sub-total: 8 regular messuages } \\
\hline \multicolumn{6}{|c|}{ THE BRIDGE } \\
\hline Richard son of Thomas & $1 \frac{1}{2}$ messuages & $8 d$ & & & \multirow{4}{*}{$\begin{array}{l}1 \frac{1}{2} \text { messuages } \\
=1.0 .24 \text { acres; } \\
1 / 2 \text { messuage }= \\
0.1 .21 \\
\text { Sum of the } \\
\text { two is } 1.2 .5\end{array}$} \\
\hline Ralph son of Richard & $\begin{array}{l}1 / 2 \text { messuage and a } \\
\text { small piece of land }\end{array}$ & $4 d$ & 2088-2094 & $\begin{array}{l}\text { 1.3.13 + buildings } \\
\text { in } 1840\end{array}$ & \\
\hline Walter Palmer, John son & 1 languetta ${ }^{5}$ & $1 / 2 \mathrm{~d}$ & & & \\
\hline $\begin{array}{l}\text { of Hugh \& john de } \\
\text { Beynwick }\end{array}$ & & & & & \\
\hline \multicolumn{6}{|c|}{ Sub-total: 2 messuages $^{6}$} \\
\hline Robert son of Richard & $\begin{array}{c}1 \text { messuage \& a plot } \\
\text { of land }\end{array}$ & $7 d$ & & & \\
\hline Eliot son of Tholy & 1 messuage & $6 d$ & 2095 & 0.3 .08 & \\
\hline Ralph son of Geoffrey & $\begin{array}{l}1 \text { messuage and a } \\
\text { plot of land }\end{array}$ & $7 d$ & 2096 & 0.3 .7 & \\
\hline
\end{tabular}

\footnotetext{
${ }^{4}$ It is difficult to be sure whether this means one full and one half messuage, or whether it means one messuage containing 1.5 times the standard area. I have interpreted it as the latter.

${ }^{5}$ It is very tempting to see this languetta as a landing place on the north side of the Nene, but there is nothing in the landscape to suggest that this was the case. The river bank remains a public right of way.

${ }^{6}$ The first two blocks of messuages east of the bridge on the north side of the Nene suggest some division and agglomeration of messuages had gone on since they were first laid out. Nonetheless they appear to show an underlying regularity.
} 


\begin{tabular}{|c|c|c|c|c|c|}
\hline Richard Gaze & $1 \frac{1}{2}$ messuages & $8 d$ & 2099 & 1.0 .27 & $\begin{array}{l}1.0 .24 \text { acres }= \\
11 \frac{1}{2} \text { messuages }\end{array}$ \\
\hline Walter le paumer & 2 messuages & $12 d$ & 2103 & 0.2 .27 & \\
\hline John Em & $2 \times 1 / 2$ messuages & $6 d$ & $2104-5$ & $0.1 .6+0.2 .8$ & $\begin{array}{l}1 / 2 \text { messuage }= \\
0.1 .21\end{array}$ \\
\hline \multicolumn{6}{|c|}{ Sub-total: 8 messuages } \\
\hline $\begin{array}{l}\text { Alice widow of Gilbert, \& } \\
\text { John son of Hugh }\end{array}$ & 1 messuage & $6 \mathrm{~d}$ & \multirow{9}{*}{$\begin{array}{l}\text { These } \\
\text { properties not } \\
\text { shown on the } \\
1840 \text { tithe } \\
\text { map }\end{array}$} & \multirow{9}{*}{ n.k. } & \multirow{9}{*}{$\begin{array}{l}\text { Shown as a } \\
\text { coherent } \\
\text { block of } 12 \\
\text { properties in } \\
\text { c. 1601-3. }\end{array}$} \\
\hline Richard clayland & 2 messuages & $12 d$ & & & \\
\hline Henry tympon & 1 messuage & $6 d$ & & & \\
\hline Geoffrey pekoe & 1 messuage & $6 d$ & & & \\
\hline Clement son of John & 1 messuage & $6 d$ & & & \\
\hline Agnes daughter of Toly & 1 messuage & $6 d$ & & & \\
\hline Robert de estiwith & 1 messuage & $6 d$ & & & \\
\hline Ralph son of Godfrey & 2 messuages & $12 d$ & & & \\
\hline Richard spirhard & 2 messuages & $12 d$ & & & \\
\hline \multicolumn{6}{|c|}{ Sub-total: 12 regular messuages } \\
\hline \multicolumn{6}{|c|}{ SOUTH BANK OF THE NENE FROM NORTH TO SOUTH } \\
\hline Walter survel & $\begin{array}{l}1 / 2 \text { messuage and a } \\
\text { plot of land }\end{array}$ & $5 d$ & & & \\
\hline Ralph son of William & $\begin{array}{l}3 \text { messuages and a } \\
\text { plot of land }\end{array}$ & $20 d$ & & & \\
\hline Peter son of Thomas & $\begin{array}{l}1 / 2 \text { messuage and a } \\
\text { plot ofland }\end{array}$ & $4 d$ & & & \\
\hline Peter chapman & $\begin{array}{c}11 \frac{1}{2} \text { messuages and a } \\
\text { plot of land }\end{array}$ & $9 d$ & & & \\
\hline Richard son of Odo & $\begin{array}{c}1 \text { messuage and } 1 \frac{1}{2} \\
\text { acres of fen }\end{array}$ & $9 d$ & & & \\
\hline \multicolumn{6}{|c|}{ Sub-total: 7 messuages $^{7}$} \\
\hline $\begin{array}{l}\text { Thomas son of Roger } \\
\text { abbot }\end{array}$ & $1 / 4$ messuage & $2 d$ & & & \\
\hline Reginald clerk & $1 / 4$ messuage & $2 d$ & & & \\
\hline Richard spirhard & $1 / 4$ messuage & $2 d$ & & & \\
\hline Richard Wynebotesham & $1 / 4$ messuage & $1 \frac{1}{2} d$ & & & \\
\hline Richard abbot & $1 / 2$ messuage & $3 d$ & & & \\
\hline \multicolumn{6}{|c|}{ Sub-total: 5 irregular messages ${ }^{8}$} \\
\hline Richard scad & 1 messuage & $6 d$ & 1697 & 1.1 .36 & \\
\hline
\end{tabular}

\footnotetext{
7 It is possible that these messuages might be identified with the properties that lay east of the open space south and east of the bridge in c.1601-1603.

8 The small areas of these properties suggest that they may have be the small encroachments against the southern side of the open space shown on the early seventeenth-century estate map.
} 


\begin{tabular}{|c|c|c|c|c|c|}
\hline John shepherd & 1 messuage & $6 d$ & \multirow[t]{2}{*}{$1699-1703$} & \multirow[t]{2}{*}{3.0 .10} & \multirow{4}{*}{$\begin{array}{l}2 \times 1.2 .0=3 \\
\text { acres }\end{array}$} \\
\hline Stephen de Stratham & 1 messuage & $6 d$ & & & \\
\hline Roger cat & 1 messuage & $6 d$ & 1704 & 1.2 .21 & \\
\hline Walter Munby & 1 messuage & $6 d$ & & & \\
\hline John Cugeray & 1 messuage & $6 d$ & $1705-7$ & 4.2 .29 & $3 \times 1.2 .0=$ \\
\hline Agnes oppere & 1 messuage & $6 d$ & & & 4.2 .0 \\
\hline Henry sapayn & 1 messuage & $6 d$ & 1708 & 1.0 .19 & \\
\hline Henry Chaumperyneys & 1 messuage & $6 d$ & $1709-11$ & 1.2.19 & \\
\hline Gilbert le coverer & 1 messuage & $6 d$ & $1712-13$ & $2.1 .28+$ buildings & $2 \times 1.2=3$ \\
\hline Richard son of Hugh & 1 messuage & $6 d$ & & & acres \\
\hline Elyot hunt & 2 messuages & $12 d$ & $1714-19$ & $5.0 .34+$ buildings & $4 \times 1.2=6$ \\
\hline Wymark sapayn & 2 messuages & $12 d$ & & & acres \\
\hline $\begin{array}{l}\text { Henry, \& Thomas son of } \\
\text { Walter }\end{array}$ & 2 messuages & $12 d$ & $1720-1$ & $\begin{array}{c}1.0 .9+1.1 .26= \\
2.1 .35 \text { acres }+ \\
\text { buildings }\end{array}$ & $\begin{array}{l}2 \times 1.2=3 \\
\text { acres }\end{array}$ \\
\hline $\begin{array}{l}\text { Reginald, \& Robert de } \\
\text { Hidele }\end{array}$ & 2 messuages & $12 d$ & 1722 & 2.1 .07 + buildings & $\begin{array}{l}2 \times 1.2=3 \\
\text { acres }\end{array}$ \\
\hline
\end{tabular}

\footnotetext{
${ }^{9}$ It will be noted that this block held more than 20 properties in c.1601-3 and in 1840 . However, the 1900 Ordnance Survey map shows that the back (eastern) boundary of the properties numbered as 1697-1722 is continuous both around the northern boundary of 1697 and around the southern boundary of 1722 . This suggests that those north of 1697 and south of 1722 are later additions to an existing planned block formed of 1697-1722. Indeed, the Ordinance Survey map shows that the back (eastern) boundary of properties 1723-1730 abuts the back boundary of those to the north (1697-1722) at a right angle.
} 
${ }^{1}$ With apologies to Jane Austen.

${ }^{2}$ CUL EDR G3.27. A messuage is essentially a toft on which a dwelling stands, the former large enough to contain in addition some agricultural outbuildings, a kitchen garden and, sometimes, a paddock (Onions 1973, 'Messuage').

${ }^{3}$ The Doddington estate was consolidated in the hands of the Abbey of Ely in the late tenth and early eleventh centuries; the new Bishopric of Ely was endowed with a large proportion of the Abbey's manors when it was established in 1109.

4 'Plantwater' Drain is now just a sinuous, partly canalised ditch, which continues the Nene's northward alignment from the point at which the modern river turns east. Phragmites, the common reed, is a plant of damp or waterlogged ground; it reaches a height of around 15 feet and spreads easily; the fen-sedge, cladium mariscus, can grow to $2.5 \mathrm{~m}$.

${ }^{5}$ Medieval and post-medieval descriptions of silting of the estuary at Wisbech provide a vivid illustration of the relentless recurrence of this problem (Stone 2005, p.29; Page, Proby and Ladds 1936, p. 253). Fenland conditions made this a recurrent problem, of course, and the construction in the fifteenth century of Bishop Morton's Leam, the artificial canal between Peterborough and Guyhirn, represents another attempt to address the same conditions.

${ }^{6}$ The herds of cattle that grazed on the rich grasses of the region were mostly driven on the hoof between vill and pasture, although boats could also be used: early fourteenth-century cattle drives in East Fen of the Soke of Bolingbroke, Lincs., were undertaken by 'a bailiff, and twenty-two men with twelve horses, and eight men with boats' (Neilson 1920, p. xiii; see also Darby 1974, p. 62).

${ }^{7}$ The estate map has been securely dated to $1601-3$ by correlating the names of landholders on the map with parish records (Walker 1894). It is, however, catalogued in the Cambridgeshire Archives and in the Cambridge University Library as c.1680. I am very grateful to Mr David Edwards for drawing Rev. Walker's convincing argument for this earlier date to my attention and for giving me a copy of his transcription of Rev Walker's text. Smaller-scale early seventeenth-century maps (some preserved as copies) show the same layout, e.g. CA R59/31/40/1, CA 59/31/40/176, CA R52/24/31). 
${ }^{8}$ While each block of properties on the map can be overlaid digitally almost exactly on the same areas in the 1840 Tithe Map or the 1900 Ordnance Survey map, there are problems in overlaying the map as a whole. It seems likely that these difficulties result from the distortion over time of a very large map on parchment (CA R51/28/1A-C; Ordnance Survey 1900).

${ }^{9}$ The plots numbered 1863-1867 on the tithe map measured 3 roods 14 perches, 3 roods 29 perches, 3 roods, 35 perches, 3 roods 16 perches, and 3 roods respectively (CA R51/28/1A-C).

${ }^{10}$ Although unusual, such detailed reconstructions of the layout and holdings of medieval settlements have been attempted before at Cuxham (Oxon.) and Kibworth Harcourt (Leices.) (Harvey 1965; Howell 1983).

${ }^{11}$ This may confirm that they were not assarts: Neilson noted that 'to tenements in assart no rights of common could pertain, since the assart itself was originally subject to the common rights of the vill' (1920, p. liv).

12 Idenhe was another name for the Plantewater (Reaney 1943, p. 14; Wells 183, p. 21).

${ }^{13}$ The east side of High Street, March' (CA P116/28/19).

14 'Somewhere on the old stream which divided Wisbech from March in Goosetree' (CA P116/28/19).

${ }^{15}$ Miller suggested that such group actions may have been focused on reclamation, but this seems unlikely. Although reclamation was common in the silt fens, there is little evidence of widespread reclamation on the peat fens (Miller 1951, p. 120; Hallam 1965).

${ }^{16}$ That is, held of the hundred but administered by the manor.

${ }^{17}$ Although far beyond the peat fens, the wealth of medieval Holderness was similarly derived from the rich summer pasturage available in its marshes rather than from any arable produce (Siddle 1967, pp. 44-5).

${ }^{18}$ Seventeenth-century farmers protesting against fen drainage described the range of products which made their herds profitable: 'we breed and feed great store of young cattle, and we keep great dayeries ... and multitudes of heyfers, and Scots and Irish cattle have been fatted on the Fens, which afford hides, and tallow' (CUL Anti-Protestor; see also Gooch 1811, p. 268).

${ }^{19}$ While the average herd in early sixteenth-century Willingham held eight cattle, the median herd in upland Orwell was two, and the former could be held by men with little or no land, while the latter tended to be restricted to customary tenants (Spufford 1974, pp. 130-1, 98-9). 